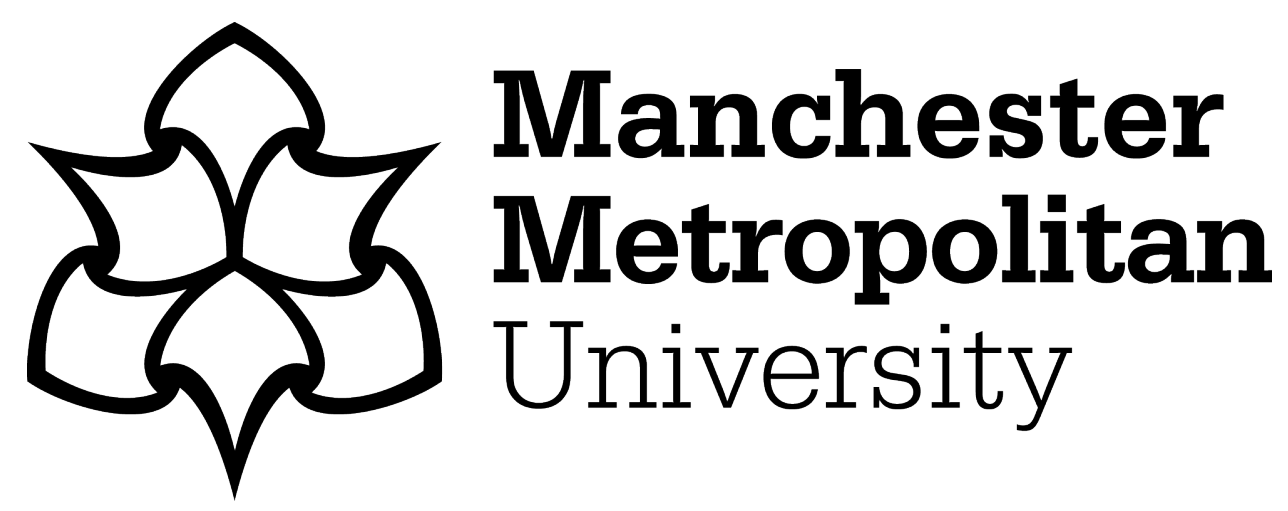

Darby, Richard AJ, Unsworth, Amanda ORCID logoORCID: https://orcid.org/0000-0003-3809-5984, Knapp, Stefan, Kerr, lan D and Callaghan, Richard (2015) Overcoming ABCG2-mediated drug resistance with imidazo-[1,2-b]-pyridazine-based Pim1 kinase inhibitors. Cancer Chemotherapy and Pharmacology, 76 (4). pp. 853-864. ISSN 0344-5704

Downloaded from: https://e-space.mmu.ac.uk/622749/

Version: Accepted Version

Publisher: Springer

DOI: https://doi.org/10.1007/s00280-015-2858-9

Please cite the published version 


\title{
Overcoming ABCG2-mediated drug resistance with imidazo-[1,2-b]-pyridazine-based Pim1 kinase inhibitors
}

\author{
Richard A. J. Darby ${ }^{1,2}$ • Amanda Unsworth ${ }^{1} \cdot$ Stefan Knapp $^{2}$ ' Ian D. Kerr ${ }^{3}$. \\ Richard Callaghan ${ }^{1,4}$
}

Received: 12 May 2015 / Accepted: 25 August 2015 / Published online: 9 September 2015

(C) Springer-Verlag Berlin Heidelberg 2015

\begin{abstract}
Purpose Multidrug efflux pumps such as ABCG2 confer drug resistance to a number of cancer types, leading to poor prognosis and outcome. To date, the strategy of directly inhibiting multidrug efflux pumps in order to overcome drug resistance in cancer has been unsuccessful. An alternative strategy is to target proteins involved in the regulation of multidrug efflux pump activity or expression. Pim1 kinase has been demonstrated to phosphorylate ABCG2, promote its oligomerisation and contribute to its ability to confer drug resistance.

Methods In the present manuscript, imidazo-pyridazinebased inhibitors of Pim1 were examined for their ability to overcome ABCG2-mediated drug resistance. Drug efficacy was measured as a cytotoxic response or an effect on transport by ABCG2. Protein expression patterns were assessed using western immuno-blotting.

Results The two Pim1 inhibitors increased the potency of flavopiridol, mitoxantrone, topotecan and doxorubicin, specifically in ABCG2-expressing cells. This effect was associated with an increase in the cellular accumulation of $\left[{ }^{3} \mathrm{H}\right]$-mitoxantrone, suggesting direct impairment of the
\end{abstract}

Richard Callaghan

richard.callaghan@anu.edu.au

1 Nuffield Department of Clinical Laboratory Sciences, John Radcliffe Hospital, University of Oxford, Headington, UK

2 Structural Genomics Consortium and Target Discovery Institute, University of Oxford, Old Road Campus, NDM Research Building, Oxford OX3 7FZ, UK

3 School of Life Sciences, University of Nottingham, Queen's Medical Centre, Nottingham NG7 2UH, UK

4 Division of Biomedical Science and Biochemistry, Research School of Biology, The Australian National University, Canberra, ACT 0200, Australia transporter. However, prolonged pre-incubation with the studied inhibitors greatly enhanced the effect on mitoxantrone accumulation. The inhibitors caused a significant time-dependent reduction in the expression of ABCG2 in the resistant cells, an effect that would improve drug efficacy.

Conclusion Consequently, it appears that the Pim1 inhibitors display a dual-mode effect on ABCG2-expressing cancer cells. This may provide a powerful new strategy in overcoming drug resistance by targeting proteins that regulate expression of efflux pumps.

Keywords Multidrug resistance - BCRP · ABCG2 - Pim1 kinase $\cdot$ Cancer chemotherapy

\section{Introduction}

Chemotherapy remains a vital treatment strategy in cancer, and unfortunately, the multidrug-resistant phenotype continues to confound its efficacy. Multidrug resistance comprises numerous cellular processes that are either inherent to the tissue or acquired during chemotherapy. The plasma membrane is at the front line of resistance and utilises a triad of drug efflux pumps from the ATP-binding cassette (ABC) family. The three pumps have distinct pharmacological profiles and distinct expression patterns in cancer. The focus of this investigation is on ABCG2, which is known to confer resistance to flavopiridol, mitoxantrone, methotrexate and topotecan $[1,2]$. The protein is expressed in cultured cell lines of fibrosarcoma, myeloma, ovarian and breast cancer. Human cancers known to express the protein include digestive tract, lung and endometrial adenocarcinomas, soft-tissue sarcomas and haematological malignancies [2-6]. At the clinical level, there are no effective 
strategies to overcome the resistant phenotype produced by ABCG2, although a number of compounds inhibit its activity in vitro. Developing strategies to overcome the action of ABCG2 are important, particularly given its wide expression profile in cancers and the number of cytotoxic drugs affected by its influence.

A homodimeric assembly of ABCG2 is required to generate a fully functional drug transport protein. The precise oligomeric status remains contentious with evidence from co-immunoprecipitation [7] and low-resolution cryo-EM studies indicating the presence of higher-order oligomers [8]. The protein is a member of the G-subfamily and comprises an amino-terminal nucleotide-binding domain (NBD) and a transmembrane domain (TMD) containing six helices [1]. This "reverse" topological arrangement is distinct from other subgroups of the ABC family. The protein is glycosylated on the asparagine at position 596 [9], which is located in the extracellular loop between TM helices 5 and 6. This loop also contains an intramolecular disulphide bond between cysteine residues at positions 592 and 608 and an intermolecular disulphide bond between pairs of cysteine 603 [10]. The precise roles of glycosylation and disulphide bond formation in ABCG2 function remain unresolved, but they are crucial to the folding and stability of the protein. The region at the interface between homodimeric units remains to be elucidated, although a GXXXG motif between positions 406 and 410 has been implicated [11].

ABCG2 has numerous consensus sites for phosphorylation, although there is little information on the state of its phosphorylation in cells $[1,12,13]$. However, phosphorylation of ABCG2 has been suggested to be a prerequisite for its expression at the plasma membrane with a report showing that activation of protein kinase $\mathrm{B}$ (AKT) results in an increase in the amount of ABCG2 at the plasma membrane, whilst inactivation of AKT results in internal retention of ABCG2 [12]. Moreover, the interaction has a functional consequence since it has been shown in haematopoietic stem cells that the efflux of the ABCG2 substrate Hoechst
33342 was positively correlated with the activity of AKT [14].

Activated AKT has also been shown to bind to the prolactin response element found on the Piml promoter [15]. Pim1 kinase is a serine/threonine kinase encoded by a proto-oncogene known to be expressed in several cancers [16]. Two isoforms of the kinase are known to be produced by alternative translation start sites yielding a 33 and $44 \mathrm{kDa}$ protein. The $44 \mathrm{kDa}$ kinase may exist as a dimer, whilst the $33 \mathrm{kDa}$ isoform is monomeric [17]. Whilst the $33 \mathrm{kDa}$ kinase regulates the cell cycle and transcription by phosphorylating numerous participants in these processes, including cdc25A, HP1 and p100 [18-21], the $44 \mathrm{kDa}$ kinase has been shown to interact with ABCG2 [13]. It has been postulated that Pim1 phosphorylates the threonine at position 362 in ABCG2, which was proposed to modulate the dimerisation and/or multimerisation of ABCG2 [13]. The Thr362 residue in ABCG2 is found in a Pim1 compatible recognition sequence: (Lys) ${ }_{3}-\mathrm{Ile}-\mathrm{Thr}-\mathrm{Val}$ [22]. In a taxane-resistant prostate cancer cell line overexpressing P-gp, treatment with SGI-1776 (a novel inhibitor of Pim1) re-sensitised the cell line to paclitaxel, suggesting a potential role for Pim1 kinase in multidrug resistance [23].

Compounds based on an imidazo-[1,2-b]-pyridazine scaffold have been found to inhibit Pim1 kinase at nanomolar affinity in vitro [24-26] by forming hydrogen bond and hydrophobic interactions with the binding pocket, thereby perturbing ATP binding. This class of compounds displays selectivity for the Pim1 kinase domain over the Pim2 isoform. K00135 and K00486 (Fig. 1) were identified as the best compounds of this series to bind to Pim1 with a high affinity and inhibit its activity [27]. The present study investigated the effects of the Pim1 kinase inhibitors K00135 and K00486 on ABCG2-mediated drug resistance in the $\mathrm{MCF}^{\mathrm{FLV} 1000}$ cell line. The data suggest that the inhibitors are able to overcome drug resistance by a dual mechanism involving direct inhibition of ABCG2 and by altering its expression.
Fig. 1 Pim inhibitor structures. The chemical structures of the Pim1 kinase inhibitors K00135 (left panel) and K00486 (right panel). The inhibitors were based on the imidazo-[1,2-b]pyridazine template molecule<smiles>CC(=O)c1cccc(Cc2cnc3ccc(NCC4CC4)nn23)c1</smiles><smiles>CCC(CO)Nc1ccc2ncc(Cc3ccc(F)c(Cl)c3)n2n1</smiles>

K00486 


\section{Materials and methods}

\section{Reagents}

The imidazo-[1,2-b]-pyridazine-based Pim1 kinase inhibitors were synthesised in the Knapp Laboratory and stored at a concentration of $50 \mathrm{mM}$ in DMSO. The ABCG2-specific inhibitor fumitremorgin C (FTC), doxorubicin, topotecan and mitoxantrone were purchased from Sigma-Aldrich and prepared as $50 \mathrm{mM}$ aliquots in DMSO. Mitoxantrone (Tocris) was prepared at $50 \mathrm{mM}$ in DMSO, and flavopiridol (Biomol International) was prepared at $10 \mathrm{mM}$ in DMSO. All compounds were stored at $-20{ }^{\circ} \mathrm{C}$. $\left[{ }^{3} \mathrm{H}\right]$-mitoxantrone $(148 \mathrm{GBq} / \mathrm{mmol})$ was purchased from Moravek Biochemicals (Brea, USA). The anti-ABCG2 (BXP-21) and the anti-Pim antibody (12H8) were purchased from Santa Cruz Biotechnology and the goat anti-mouse horseradish peroxidase-conjugated antibody from DAKO. The ECL Prime chemi-luminescence detection kit was purchased from GE. All plasticware was purchased from either Fisher Scientific UK or Greiner Bio-One.

\section{Cell lines}

A549 (lung), DLD-1 (colorectal), H226 (lung), HT-29 (colorectal), $\mathrm{LnCaP}$ (prostate), PC3 (prostate), MCF7 (breast) and the ABCG2-overexpressing MCF7 ${ }^{\mathrm{FLV} 1000}$ cell lines were cultured in RPMI 1640 medium (Invitrogen Life Technologies) supplemented with $10 \%$ foetal calf serum and $1 \%$ penicillin/streptomycin (Lonza). Flavopiridol (500 nM) was added to the medium of the MCF7 ${ }^{\mathrm{FLV} 1000}$ cell line every fourth subculture to maintain selection pressure for ABCG2 expression. Cells were maintained for a further passage before use. The Jurkat and K562 leukaemic cell lines were grown under similar conditions but as suspension cultures. The P-gp-expressing and drug-resistant $\mathrm{NCI} / \mathrm{ADR}^{\text {Res }}$ cell line was cultured in the presence of $3 \mathrm{mM}$ doxorubicin for a single passage every ten passages to maintain the selection pressure The resistant NCI/ ADRRes cell line was cultured in the presence of $3 \mu \mathrm{M}$ doxorubicin for a single passage every ten passages to maintain the selection pressure [35]. This cell line was formerly known as the MCF7Adr line and has been redesignated as described in Ref. [23, 28].

\section{Cytotoxicity assays}

Cells were seeded in flat-bottomed 96-well plates at a density of 2500 cells per well and allowed to attach to the surface for $24 \mathrm{~h}$ at $37{ }^{\circ} \mathrm{C}, 5 \% \mathrm{CO}_{2}$. The effects of single drug treatment on the viability of the cell lines were evaluated after incubation for 5 days with various concentrations of Pim kinase inhibitors $\left(10^{-8}-10^{-4} \mathrm{M}\right)$ or chemotherapeutic agents $\left(10^{-12}-10^{-4} \mathrm{M}\right)$.
For combination drug treatment, MCF7 and MCF$7^{\text {FLV1000 }}$ cell lines were incubated with chemotherapeutic agents $\left(10^{-12}-10^{-4} \mathrm{M}\right)$ in the absence or presence of FTC $(0.3 \mu \mathrm{M}), \mathrm{K} 00135(0.1$ or $0.3 \mu \mathrm{M}), \mathrm{K} 00486(0.3$ or $1.0 \mu \mathrm{M})$ or an equivalent volume of DMSO as a vehicle/solvent control and allowed to incubate for 5 days at $37{ }^{\circ} \mathrm{C}, 5 \% \mathrm{CO}_{2}$. Cells were subsequently fixed in $10 \%$ trichloroacetic acid for $30 \mathrm{~min}$ at $4{ }^{\circ} \mathrm{C}$. The plates were then washed with five rounds of water and stained with $0.075 \%$ (w/v) sulforhodamine B (SRB) for $15 \mathrm{~min}$ at room temperature. Excess SRB was removed from the plates with four washes of $1 \%(\mathrm{v} / \mathrm{v})$ acetic acid and the SRB-stained viable cells solubilised with $10 \mathrm{mM}$ Trizma pH10.5. Absorbance was detected on a SpectraMax Plus 384 (Molecular Devices) at $540 \mathrm{~nm}$ using SoftMax ${ }^{\circledR}$ Pro data acquisition and analysis software. For the nonadherent leukaemia cells, the MTS assay was used to measure cell density and viability as described [29].

Data from either assay were subsequently analysed and graphically depicted using GraphPad Prism software, using one-way ANOVA. Drug toxicity was quantified by nonlinear regression of the general dose-response equation:

$F=F_{\min }+\frac{F_{\max }-F_{\min }}{1+10^{\left(\log _{10}\left(\mathrm{IC}_{50}\right)-[D]\right)}}$

where $F$ is the viable cell number, $F_{\text {max }}$ and $F_{\text {min }}$ are the maximum and minimum cell number, respectively, $\mathrm{IC}_{50}$ is the concentration causing $50 \%$ cell death, and $[D]$ is the logarithm of drug concentration. At least four independent experiments were performed, and relative resistance values were established by dividing the $\mathrm{IC}_{50}$ value of the $\mathrm{MCF} 7^{\mathrm{FLV} 1000}$ cell line for each drug by the $\mathrm{IC}_{50}$ value of the MCF7 cell line.

\section{Cellular accumulation of $\left[{ }^{3} \mathrm{H}\right]$-mitoxantrone}

ABCG2-mediated transport was assessed by the steadystate accumulation of $\left[{ }^{3} \mathrm{H}\right]$-mitoxantrone. Fifty thousand cells well ${ }^{-1}$ were seeded in sterile 24 -well plates and incubated at $37{ }^{\circ} \mathrm{C}, 5 \% \mathrm{CO}_{2}$ overnight. Pim1 kinase inhibitors or FTC was added to the wells and allowed to incubate for various times as specifically indicated in the results. The medium was subsequently discarded from the plate and replaced with $0.5 \mathrm{ml}$ of drug transport buffer $(107 \mathrm{mM}$ $\mathrm{NaCl}, 10 \mathrm{mM}$ Tris. $\mathrm{HCl}$ pH7.4, 26 mM NaHCO $3,5.3 \mathrm{mM}$ $\mathrm{KCl}, 1.9 \mathrm{mM} \mathrm{CaCl}$, $1 \mathrm{mM} \mathrm{MgCl}_{2}, 7 \mathrm{mM}$ glucose) containing a total mitoxantrone concentration of $1 \mu \mathrm{M}$, which contained $40 \mathrm{nM}$ of the tracer $\left[{ }^{3} \mathrm{H}\right]$-mitoxantrone. FTC or Pim kinase inhibitor were also added to the transport buffer with radioligand where required. The plate was incubated as above for a period of $3 \mathrm{~h}$ before discarding the buffer and washing the wells three times with $0.5 \mathrm{ml}$ of ice-cold PBS. The cells were lysed with $0.5 \mathrm{ml} 0.1 \mathrm{M} \mathrm{NaOH}$ and the 
Table 1 Effects of Pim1 inhibitors on the growth of cultured human cancer cells

\begin{tabular}{|c|c|c|c|c|c|c|c|c|}
\hline Drug & K562 & Jurkat & PC3 & LNCaP & HT-29 & $\mathrm{H} 226$ & DLD-1 & A549 \\
\hline $\mathrm{K} 00135(\mu \mathrm{M})$ & $12 \pm 6$ & $2.0 \pm 1.1$ & $4.7 \pm 2.0$ & $3.9 \pm 0.4$ & $19 \pm 16$ & $13 \pm 5$ & $11 \pm 5$ & $28 \pm 4$ \\
\hline $\mathrm{K} 00486(\mu \mathrm{M})$ & $3.9 \pm 1.4$ & $1.3 \pm 0.5$ & $4.4 \pm 1.5$ & $2.0 \pm 0.5$ & $11 \pm 5$ & $3.8 \pm 2.3$ & $4.4 \pm 1.7$ & $13 \pm 8$ \\
\hline Cisplatin $(\mu \mathrm{M})$ & $5.2 \pm 1.8$ & $1.8 \pm 0.9$ & $3.8 \pm 1.7$ & $12 \pm 8$ & $4.7 \pm 1.2$ & $14 \pm 5$ & $11 \pm 6$ & $19 \pm 6$ \\
\hline Etoposide (nM) & $44 \pm 8$ & $89 \pm 39$ & $287 \pm 47$ & $175 \pm 25$ & $530 \pm 170$ & $102 \pm 40$ & $250 \pm 119$ & $467 \pm 133$ \\
\hline Methotrexate (nM) & $2.7 \pm 0.6$ & $19 \pm 9$ & $0.67 \pm 0.67$ & $54 \pm 19$ & $10 \pm 4$ & $41 \pm 17$ & $25 \pm 9$ & $37 \pm 11$ \\
\hline Doxorubicin (nM) & $3.2 \pm 0.8$ & $2.5 \pm 0.5$ & $22 \pm 4$ & $7.6 \pm 2.5$ & $26 \pm 10$ & $66 \pm 59$ & $9.6 \pm 2.3$ & $47 \pm 31$ \\
\hline Vinblastine (nM) & $0.04 \pm 0.01$ & $0.04 \pm 0.01$ & $0.15 \pm 0.07$ & $0.11 \pm 0.06$ & $0.31 \pm 0.10$ & $0.29 \pm 0.14$ & $1.81 \pm 0.91$ & $0.76 \pm 0.35$ \\
\hline Mitoxantrone (nM) & $2.6 \pm 0.8$ & $0.11 \pm 0.07$ & $4.8 \pm 1.4$ & $1.6 \pm 0.6$ & $6.4 \pm 3.4$ & $0.84 \pm 0.32$ & $3.2 \pm 0.7$ & $2.2 \pm 0.3$ \\
\hline
\end{tabular}

Cells were seeded at $2 \times 10^{3}$ cells per well (total volume $=100 \mu \mathrm{l}$ ) in a 96-well tissue culture plate and incubated for $24 \mathrm{~h}$ prior to addition of drugs. Anti-cancer drugs and the two Pim kinase inhibitors were prepared in medium at double the desired concentration and $100 \mu l$ added to each well. Vinblastine was added in the final concentration range $10^{-12}-10^{-5} \mathrm{M}$ and all other drugs in the range $10^{-10}-10^{-4} \mathrm{M}$. Cells were incubated for $96 \mathrm{~h}$ with the drugs. Cell number and viability were measured with the SRB assay for adherent cultures and with MTS for suspension cultures (i.e. K562 and Jurkat). Cell density was plotted as a function of cytotoxic drug concentration and the $\mathrm{IC}_{50}$ values (units shown in parentheses) determined using nonlinear regression of the general dose-response equation. The values shown represent mean \pm SEM from four to six independent experiments

amount of mitoxantrone determined by liquid scintillation with $3.5 \mathrm{ml}$ of ReadyProtein scintillation fluid for $5 \mathrm{~min}$. The radioactive decay was converted to nmoles of mitoxantrone accumulated per milligram of cell protein using the specific activity of the radioligand.

\section{Western immuno-blot analysis}

Cells were washed with PBS and lysed with $1 \%$ (w/v) SDS and subsequently sheared with a fine gauge needle. Protein concentration was determined using the detergent compatible DC Bio-Rad assay using BSA as a standard. Samples of lysate (5-20 $\mu \mathrm{g}$ as indicated in figure legends) were subjected to SDS-PAGE using $10 \%$ (w/v) gels and then transferred to nitrocellulose. The nitrocellulose was blocked for $1 \mathrm{~h}$ with $5 \%(\mathrm{w} / \mathrm{v})$ nonfat dried milk in PBS containing $0.1 \%$ (v/v) Tween 20. The antibodies were diluted according to the manufacturer's protocols in $5 \%(\mathrm{w} / \mathrm{v})$ nonfat dried milk in PBS containing $0.1 \%$ (v/v) Tween 20 and incubated with the nitrocellulose overnight. Following washing in PBS containing $0.1 \%$ (v/v) Tween 20, the nitrocellulose was incubated with goat anti-mouse HRP secondary antibody for $1 \mathrm{~h}$. The immuno-blots were developed using ECL Prime chemi-luminescence according to the manufacturer's instructions, exposed to Hyperfilm ECL and analysed by densitometry using ImageJ software.

\section{Results}

Imidazo-[1,2-b]-pyridazine inhibitors have previously been demonstrated to interact with the nucleotide-binding site of Pim1. The two inhibitors (K00135 and K00486) used in this investigation (Fig. 1) were generated from structureactivity relationships with Pim1, and they represent two of the most potent available Pim1 inhibitors.

\section{Growth inhibitory effects of Pim1 kinase inhibitors in cultured cancer cell lines}

Initial studies with Pim1 kinase inhibitors explored their ability to prevent cell growth in a range of tumour cell lines including leukaemia and lymphoma cells, and cell lines derived from solid tumours. Both Pim1 inhibitors produced growth arrest in all the investigated cell lines in the micromolar range (Table 1), with potencies that did not differ significantly between K00135 and K00486; however, there were differences in potency when comparing between cell lines. Table 1 also shows the relative potencies of Pim1 inhibitors in comparison with conventional cytotoxic anti-cancer drugs in a number of cell lines derived from solid tumours. All cell lines used in this table express the Pim1 protein, and none have ABCG2 expression at levels detectable by western blotting (data not shown). The data were obtained following a 96-h exposure of cells to cytotoxic drugs or Pim1 inhibitors. Shorter incubation (24 h) with the Pim1 inhibitors did not alter the efficacy (i.e. the maximal effect on growth arrest), although the potencies of each compound were marginally reduced (data not shown). The Pim1 inhibitors are regarded as anti-proliferative agents, and therefore, the longer incubation period was chosen for comparison with the effects of cytotoxic anti-cancer drugs. As expected, the various anti-cancer drugs displayed considerable variation in the $\mathrm{IC}_{50}$ values for cytotoxicity, with a rank order of potency of: vinblastine $>$ doxorubicin $>$ mitoxantrone $>$ etoposide $>$ cisplatin . 


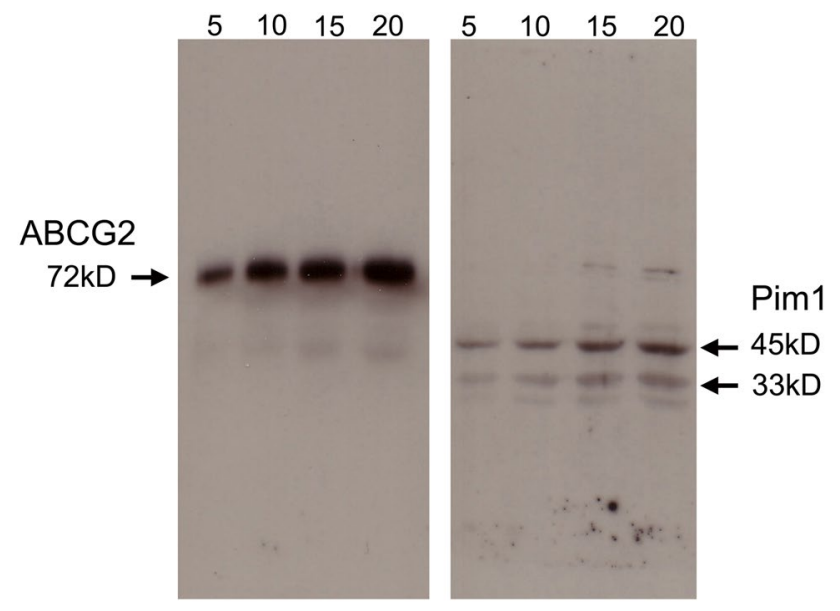

Fig. 2 Expression of ABCG2 and Pim1 in breast cancer cells. Cell lysates were prepared from the drug-resistant $\mathrm{MCF}^{\mathrm{FLV} 1000}$ cell line in $1 \%$ SDS and total protein determined colorimetrically. SDS-PAGE (10\% gels) and western blot analysis was performed on lysate samples containing 5, 10, 15 and $20 \mu \mathrm{g}$ protein. The amounts loaded $(\mu \mathrm{g})$ on each well are denoted by the values above the lanes. The left panel shows a blot probed with the anti-ABCG2 antibody BXP-21. The arrow indicates the location of the $72 \mathrm{kD}$ ABCG2 protein. The blot shown in the right panel was probed with the anti-Pim antibody 12H8. The arrows correspond to the 33 and $45 \mathrm{kD}$ isoforms of Pim1 kinase. Both proteins were detected using an anti-mouse secondary antibody with subsequent chemi-luminescence

The anti-cancer drugs displayed potencies in the nanomolar range, with the exception of cisplatin, which was effective at micromolar concentrations.

The primary focus of the investigation was to examine the relative efficacy of Pim1 inhibitors between drugsensitive and multidrug-resistant cells expressing the $\mathrm{ABC}$ transporter $\mathrm{ABCG} 2$. The breast cancer cell line $\mathrm{MCF}^{\mathrm{WT}}$ was exposed to increasing concentrations of flavopiridol to select for drug-resistant cells as described [2]. The resultant drug-resistant cell line is referred to as MCF7 ${ }^{\mathrm{FLV} 1000}$, and as shown in Fig. 2, it is associated with expression of ABCG2. Furthermore, the cell line displays expression of the $45 \mathrm{kD}$ and the $33 \mathrm{kD}$ isoforms of Pim kinase. The parental $\mathrm{MCF}^{\mathrm{WT}}$ cell line does not express $\mathrm{ABCG} 2$ at levels detected by western immuno-blotting; however, it does express both Pim1 isoforms (data not shown). Figure 3a demonstrates that K00135 produces growth inhibitory effects on the $\mathrm{MCF}^{\mathrm{WT}}\left(\mathrm{IC}_{50}=2.7 \pm 0.5 \mu \mathrm{M}\right)$ and MCF$7^{\mathrm{FLV} 1000}$ cell lines $\left(\mathrm{IC}_{50}=1.1 \pm 0.3 \mu \mathrm{M}\right)$. The small differences in relative Pim1 inhibitor sensitivity of the two cell lines were not statistically significant, although the data were described by different relationships. Curve fitting of the variable slope and unity slope dose-response relationships was compared using an $F$ test. A variable slope equation provided the most suitable $(F$ test; $P<0.001)$ fit to the experimental data with $\mathrm{MCF} 7^{\mathrm{WT}}$ cells characterised
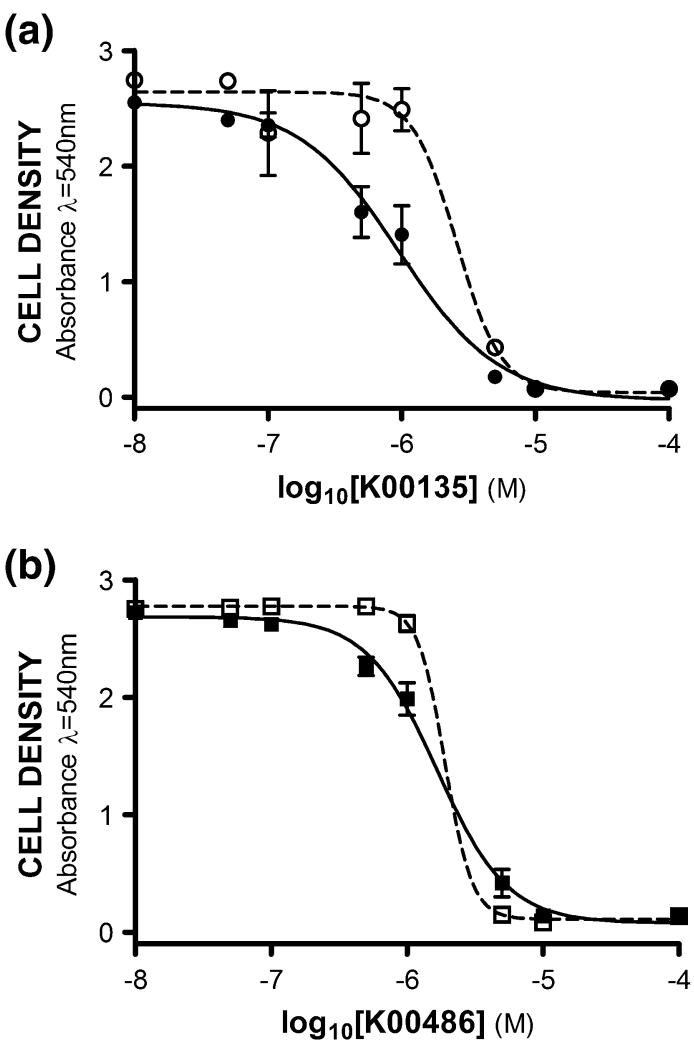

Fig. 3 Anti-proliferative effects of the imidazo-[1,2-b]-pyridazinebased Pim1 kinase inhibitors on breast cancer cells. The growth inhibitory effects of a K00135 and b K00486 were measured in MCF7 (open symbols, dashed lines) and MCF7 ${ }^{\mathrm{FLV} 1000}$ (closed symbols, solid lines $)$ cell lines. Cells $\left(2.5 \times 10^{3}\right.$ well $\left.^{-1}\right)$ were seeded in 96-well plates and grown with various concentrations $\left(10^{-8}-10^{-4} \mathrm{M}\right)$ of the inhibitors for 5 days. The cell density following incubation with inhibitors was measured using the sulforhodamine B assay. The data were fitted with the variable slope dose-response curve using nonlinear regression and shown are the mean \pm SD of three independent experiments

by a slope of -2.6 , whereas the $\mathrm{MCF}^{\mathrm{FLV} 1000}$ cells were best described by the equation with a slope of 1.0. Data for the effects of K00486 on the growth of both cell lines are shown in Fig. 3b. K00486 inhibited growth of MCF7 ${ }^{\text {WT }}$ cells with an $\mathrm{IC}_{50}$ of $1.9 \pm 0.2 \mu \mathrm{M}$ and with an $\mathrm{IC}_{50}$ of $2.6 \pm 0.1 \mu \mathrm{M}$ in the $\mathrm{MCF} 7^{\mathrm{FLV} 1000}$ cells. The experimental data in the parental cells were again best described with a variable slope ( $F$ test; $P<0.0001)$ with a value of -4.4 . The difference is likely due to the complexity of eliciting cytotoxicity in cell lines that had been selected for drug resistance. The slope factor did not influence the value of potency $\left(\mathrm{IC}_{50}\right)$ to produce a cytotoxic effect.

The similarity in potency for the Pim1 kinase inhibitors on drug-sensitive and drug-resistant (ABCG2-overexpressing) cells suggests that the compounds are not substrates for transport by $\mathrm{ABCG} 2$. 
Table 2 Effects of Pim1 inhibitors on anti-cancer drug efficacy in MCF7 and MCF7 ${ }^{\mathrm{FLV} 1000}$ cells

\begin{tabular}{|c|c|c|c|c|c|c|c|}
\hline \multirow[t]{2}{*}{ Cytotoxic drug } & \multirow[t]{2}{*}{ Cell line } & \multicolumn{6}{|c|}{ Chemosensitisation agent } \\
\hline & & Control & $\begin{array}{l}\text { FTC } \\
0.3 \mu \mathrm{M}\end{array}$ & $\begin{array}{l}\mathrm{K} 00135 \\
0.1 \mu \mathrm{M}\end{array}$ & $\begin{array}{l}\mathrm{K} 00135 \\
0.3 \mu \mathrm{M}\end{array}$ & $\begin{array}{l}\mathrm{K} 00486 \\
0.3 \mu \mathrm{M}\end{array}$ & $\begin{array}{l}\mathrm{K} 00486 \\
1.0 \mu \mathrm{M}\end{array}$ \\
\hline \multirow[t]{3}{*}{ Flavopiridol } & MCF7 & $52.6 \pm 7.3$ & $42.7 \pm 5.9$ & $57.7 \pm 4.6$ & $52.7 \pm 5.9$ & $44.7 \pm 6.6$ & $40.4 \pm 5.3$ \\
\hline & $\mathrm{MCF}^{\mathrm{FLV} 1000}$ & $2017 \pm 78$ & $193 \pm 30^{*}$ & $728 \pm 87^{*}$ & $201 \pm 20 *$ & $347 \pm 24^{*}$ & $153 \pm 11^{*}$ \\
\hline & Resistance & 38.3 & 4.5 & 12.6 & 3.8 & 7.8 & 3.8 \\
\hline \multirow[t]{3}{*}{ Mitoxantrone } & MCF7 & $12.9 \pm 3.1$ & $5.9 \pm 1.9$ & $8.7 \pm 1.8$ & $6.2 \pm 0.9$ & $6.3 \pm 2.9$ & $6.4 \pm 1.7$ \\
\hline & $\mathrm{MCF}^{\mathrm{FLV} 1000}$ & $525 \pm 69$ & $86 \pm 4 *$ & $209 \pm 51^{*}$ & $81 \pm 21 *$ & $174 \pm 49 *$ & $35 \pm 12 *$ \\
\hline & Resistance & 40.7 & 15.5 & 24.1 & 13.1 & 27.4 & 5.4 \\
\hline \multirow[t]{3}{*}{ Topotecan } & MCF7 & $8.1 \pm 1.3$ & $4.5 \pm 0.4$ & $6.3 \pm 0.7$ & $5.2 \pm 0.5$ & $6.8 \pm 1.1$ & $4.9 \pm 0.8$ \\
\hline & $\mathrm{MCF}^{\mathrm{FLV} 1000}$ & $2736 \pm 127$ & $163 \pm 27 *$ & $1315 \pm 86^{*}$ & $353 \pm 32 *$ & $571 \pm 15^{*}$ & $177 \pm 13^{*}$ \\
\hline & Resistance & 336 & 35.9 & 210 & 68.1 & 83.6 & 35.8 \\
\hline \multirow[t]{3}{*}{ Doxorubicin } & MCF7 & $8.5 \pm 0.8$ & $9.0 \pm 1.2$ & $11.1 \pm 0.52$ & $6.6 \pm 0.6$ & $12.8 \pm 2.1$ & $9.7 \pm 1.1$ \\
\hline & $\mathrm{MCF}^{\mathrm{FLV} 1000}$ & $69.9 \pm 6.9$ & $29.8 \pm 3.7$ & $62.6 \pm 3.3^{*}$ & $34.7 \pm 4.8^{*}$ & $34 \pm 4.2^{*}$ & $24.5 \pm 3.6^{*}$ \\
\hline & Resistance & 8.2 & 3.3 & 5.6 & 5.2 & 2.7 & 2.5 \\
\hline
\end{tabular}

Cells were seeded at $2 \times 10^{3}$ cells per well in a 96-well tissue culture plate and incubated for $24 \mathrm{~h}$ prior to drug addition. Cytotoxic drugs were then added to the cells in the presence or absence of Pim1 inhibitors and the ABCG2 inhibitor fumitremorgin C. The plates were incubated for a further 5 days and the cell density measured using the sulforhodamine B assay. Cell density was plotted as a function of cytotoxic drug concentration and the $\mathrm{IC}_{50}$ values $(\mu \mathrm{M})$ determined using nonlinear regression of the general dose-response equation. The values shown represent mean \pm SEM from four independent experiments. The degree of resistance refers to the ratio of cytotoxic potency in the MCF $7^{\mathrm{FLV} 1000}$ compared to the MCF7 cells. The symbol $(*)$ represents a statistically significant $(P<0.01)$ difference from the control group (i.e. no Pim1 or ABCG2 inhibitor). Statistical comparisons were made using ANOVA, with the Bartlett's post hoc test

\section{Chemosensitisation of MCF7 ${ }^{\mathrm{FLV} 1000}$ cells by Pim1 kinase inhibitors}

The ability of Pim1 inhibitors to produce growth inhibition even in drug-resistant cell lines suggests that they may facilitate the activity of conventional anti-cancer drugs. Therefore, the potency and efficacy of a series of genotoxic anti-cancer drugs in the absence or presence of Pim1 inhibitors were assessed in MCF7 and MCF7 ${ }^{\mathrm{FLV} 1000}$ cells. Dose-response analysis was used to generate an $\mathrm{IC}_{50}$ for the anti-cancer drug and the degree of resistance calculated (Table 2). The concentrations of Pim1 inhibitors used were threefold to tenfold lower than the $\mathrm{IC}_{50}$ values obtained for their ability to effect cell growth when added alone.

The cyclin-dependent kinase inhibitor flavopiridol inhibited growth of the parental MCF7 cell line with an $\mathrm{IC}_{50}$ of $52.6 \pm 7.3 \mathrm{nM}$, and the potency was reduced to $2017 \pm 78 \mathrm{nM}$ in the ABCG2-expressing $\mathrm{MCF}^{\mathrm{FLV} 1000}$ cells. The ratio of $\mathrm{IC}_{50}$ values indicates that the level of resistance to this drug was 38 -fold. In the presence of the ABCG2 inhibitor FTC $(0.3 \mu \mathrm{M})$, there was no significant effect on potency in MCF7 cells; however, the $\mathrm{IC}_{50}$ value was reduced to $193 \pm 30 \mathrm{nM}$ in the resistant line. The reduced potency revealed a significant reduction in the level of resistance to 4.5 -fold by inhibiting the activity of ABCG2. Addition of Pim1 inhibitors also caused significant increase in the potency of flavopiridol and in each case reduces the level of drug resistance. Neither compound altered the efficacy or potency of Flavopiridol to generate growth inhibition in the drug-sensitive MCF7 cells.

Mitoxantrone, a topoisomerase II inhibitor, also displayed reduced potency in drug-resistant $\mathrm{MCF} 7^{\mathrm{FLV} 1000}$ cells $\left(\mathrm{IC}_{50}=525 \pm 69 \mathrm{nM}\right)$ compared to the parental MCF7 cells $\left(\mathrm{IC}_{50}=12.9 \pm 3.1 \mathrm{nM}\right)$. This 40 -fold resistance to mitoxantrone was reduced to 15 -fold by $0.3 \mu \mathrm{M}$ FTC. In the MCF7 ${ }^{\mathrm{FLV} 1000}$ cells, the Pim1 inhibitor K00135 reduced the level of mitoxantrone resistance to 24-fold at a concentration of $0.1 \mu \mathrm{M}\left(\mathrm{IC}_{50}=209 \pm 51 \mathrm{nM}\right)$ and a further reduction to 13 -fold at a concentration of $0.3 \mu \mathrm{M}$ $\left(\mathrm{IC}_{50}=81 \pm 21 \mathrm{nM}\right)$. Similar reductions in mitoxantrone resistance were obtained for K00486, and once again, there were no effects of Pim1 inhibitors on the cytotoxicity of mitoxantrone towards MCF7 cells.

The greatest level of drug resistance observed in the MCF7 ${ }^{\text {FLV1000 }}$ cells (336-fold) was conferred against the topoisomerase I inhibitor topotecan. The potency of topotecan was improved from $\mathrm{IC}_{50}=2736 \pm 127 \mathrm{nM}$ to $\mathrm{IC}_{50}=163 \pm 27 \mathrm{nM}$ in the presence of $0.3 \mu \mathrm{M}$ FTC, which represents a reduction in the level of resistance to 35-fold. The Pim1 inhibitor K00486 (1.0 $\mu \mathrm{M})$ also reduced the level of topotecan resistance to 35 -fold and improved the potency of the cytotoxic drug to $177 \pm 13$ nM. K00135 also improved the potency of topotecan, although the level of improvement was not as large as observed for K00486 at the concentrations tested. 
Table 3 Effects of verapamil and Pim1 inhibitors on anti-cancer drug efficacy in MCF7 and ABCB1-expressing NCI ${ }^{\mathrm{ADR} / \mathrm{Res}}$ cell lines

\begin{tabular}{llllllll}
\hline Cytotoxic drug & Cell line & \multicolumn{2}{l}{ Chemosensitisation agent } \\
\cline { 3 - 7 } & & Control & $\begin{array}{l}\text { Verapamil } \\
3 \mu \mathrm{M}\end{array}$ & $\begin{array}{l}\text { K00486 } \\
0.3 \mu \mathrm{M}\end{array}$ & $\begin{array}{l}\text { K00486 } \\
1 \mu \mathrm{M}\end{array}$ & $\begin{array}{l}\text { K00135 } \\
0.1 \mu \mathrm{M}\end{array}$ & $\begin{array}{l}\mathrm{K} 00135 \\
0.3 \mu \mathrm{M}\end{array}$ \\
\hline Doxorubicin & MCF7 & $4.2 \pm 1.4$ & $2.7 \pm 0.5$ & $3.3 \pm 1.0$ & $4.1 \pm 1.0$ & $4.5 \pm 1.2$ & $3.4 \pm 0.7$ \\
& NCI ${ }^{\text {ADR/Res }}$ & $2211 \pm 387$ & $86 \pm 14^{*}$ & $2076 \pm 557$ & $2232 \pm 627$ & $2950 \pm 780$ & $3094 \pm 786$ \\
& Resistance & 526 & 32 & 629 & 544 & 655 & 910 \\
\hline
\end{tabular}

Cells were seeded at $2 \times 10^{3}$ cells per well in a 96-well tissue culture plate and incubated for $24 \mathrm{~h}$ prior to drug addition. Cytotoxic drugs were then added to the cells in the presence or absence of Pim1 inhibitors and the ABCB1 inhibitor verapamil. The plates were incubated for a further 5 days and the cell density measured using the SRB assay. Cell density was plotted as a function of cytotoxic drug concentration and the $\mathrm{IC}_{50}$ values $(\mathrm{nM})$ determined using nonlinear regression of the general dose-response equation. The values shown represent mean \pm SEM from four independent observations. The degree of resistance refers to the ratio of cytotoxic potency in the MCF7 ${ }^{\mathrm{FLV} 1000}$ compared to the MCF7 cells. The symbol (*) represents a statistically significant $(P<0.01)$ difference from the control group (i.e. no Pim1 or ABCB1 inhibitor). Statistical comparisons were made using ANOVA, with the Bartlett's post hoc test

The well-characterised R482G mutant isoform of ABCG2 imparts a number of changes in the cross-resistance pattern compared to the wild-type isoform. The latter has a considerably lower degree of resistance to the widely used anthracycline doxorubicin. Table 2 demonstrates that the degree of resistance in MCF7 ${ }^{\mathrm{FLV} 1000}$ cells compared to their parental control was only eightfold, which was lower than the other compounds tested. Nonetheless, the degree of resistance was reduced to threefold by the ABCG2 inhibitor FTC at a concentration of $0.3 \mu \mathrm{M}$. Both K00135 and K00486 were able to potentiate the cytotoxicity of doxorubicin in the MCF7 ${ }^{\mathrm{FLV} 1000}$ cells, but not the parental control.

The data in Table 2 demonstrate that expression of ABCG2 confers resistance to a number of anti-cancer drugs and that pharmacological inhibition of this transporter (by FTC) can overcome the phenotype. More importantly, inhibitors of Pim1 also produce a dose-dependent reduction in the degree of resistance by augmenting the potency of each of the anti-cancer drugs tested. The mechanism underlying how Pim1 inhibitors improve the potency of anti-cancer drugs requires further investigation.

The ability of K00135 and K00486 to overcome multidrug resistance in cells expressing $\mathrm{ABCB} 1$ was assessed using a similar strategy. As shown in Table 3, the NCIADR/Res cell line that expresses ABCB1 displayed considerable resistance (526-fold) to doxorubicin compared to the parental MCF7 cells. The ABCB1 inhibitor verapamil $(3 \mu \mathrm{M})$ increased the potency of doxorubicin from $\mathrm{IC}_{50}=2736 \pm 127 \mathrm{nM}$ to $\mathrm{IC}_{50}=86 \pm 14 \mathrm{nM}(P<0.05)$, exclusively in the drug-resistant cells. This represents a reduction in the degree of resistance from 526- to 32-fold. However, the addition of Pim1 inhibitors did not cause any alteration in the potency of doxorubicin or the degree of resistance. This indicates that the two compounds K00135 and $\mathrm{K} 00486$ produced inhibition specific to $\mathrm{ABCG} 2$ and not ABCB1.

\section{The effects of Pim1 inhibitors on the steady-state accumulation of $\left[{ }^{3} \mathrm{H}\right]$-mitoxantrone in $\mathrm{MCF}^{\mathrm{FLV} 1000}$ cells}

The Pim1 inhibitors were shown in the previous section to overcome drug resistance to a number of anti-cancer drugs in cell lines selected for resistance to flavopiridol. The drug resistance of $\mathrm{MCF}^{\mathrm{FLV} 1000}$ is primarily due to overexpression of the $\mathrm{ABC}$ transporter ABCG2. Consequently, the mechanism underlying the circumvention of drug resistance by the inhibitors is likely to involve altered accumulation of anti-cancer drugs. To investigate this mechanistic issue, the steady-state accumulation of the ABCG2 substrate $\left[{ }^{3} \mathrm{H}\right]$-mitoxantrone was investigated in the two cell lines. Initially, the accumulation was measured in the presence, or absence, of the specific ABCG2 inhibitor FTC as shown in Fig. 4a. An incubation period of $3 \mathrm{~h}$ was required to achieve steady-state accumulation of the radiolabelled drug at a total concentration of $1 \mu \mathrm{M}$. The accumulation of $\left[{ }^{3} \mathrm{H}\right]$-mitoxantrone in MCF7 cells was $2.44 \pm 0.22 \mathrm{pmol} \mathrm{mg}^{-1}$ in the absence of FTC, and the value was $1.47 \pm 0.15 \mathrm{pmol} \mathrm{mg}^{-1}$ in $\mathrm{MCF}^{\mathrm{FLV} 1000}$ cells, which represents a statistically significant difference $(P<0.005)$. The addition of increasing concentrations of FTC $(0.5-10 \mu \mathrm{M})$ did not alter the accumulation of $\left[{ }^{3} \mathrm{H}\right]-$ mitoxantrone in the MCF7 cells since the level at the highest FTC concentration $\left(2.62 \pm 0.21 \mathrm{pmol} \mathrm{mg}^{-1}\right)$ was not significantly different from the control value. In contrast, the ABCG2 inhibitor produced a dose-dependent increase in the accumulation of $\left[{ }^{3} \mathrm{H}\right]$-mitoxantrone in $\mathrm{MCF} 7^{\mathrm{FLV} 1000}$ cells to a level $\left(2.61 \pm 0.36 \mathrm{pmol} \mathrm{mg}^{-1}\right.$ at $10 \mu \mathrm{M}$ FTC $)$ that was identical to the sensitive MCF7 cells.

Parallel analysis was undertaken to assess the ability of Pim1 kinase inhibitors to modulate the steady-state accumulation of $\left[{ }^{3} \mathrm{H}\right]$-mitoxantrone. These experiments were carried out either with the Pim1 kinase inhibitor present 
(a)
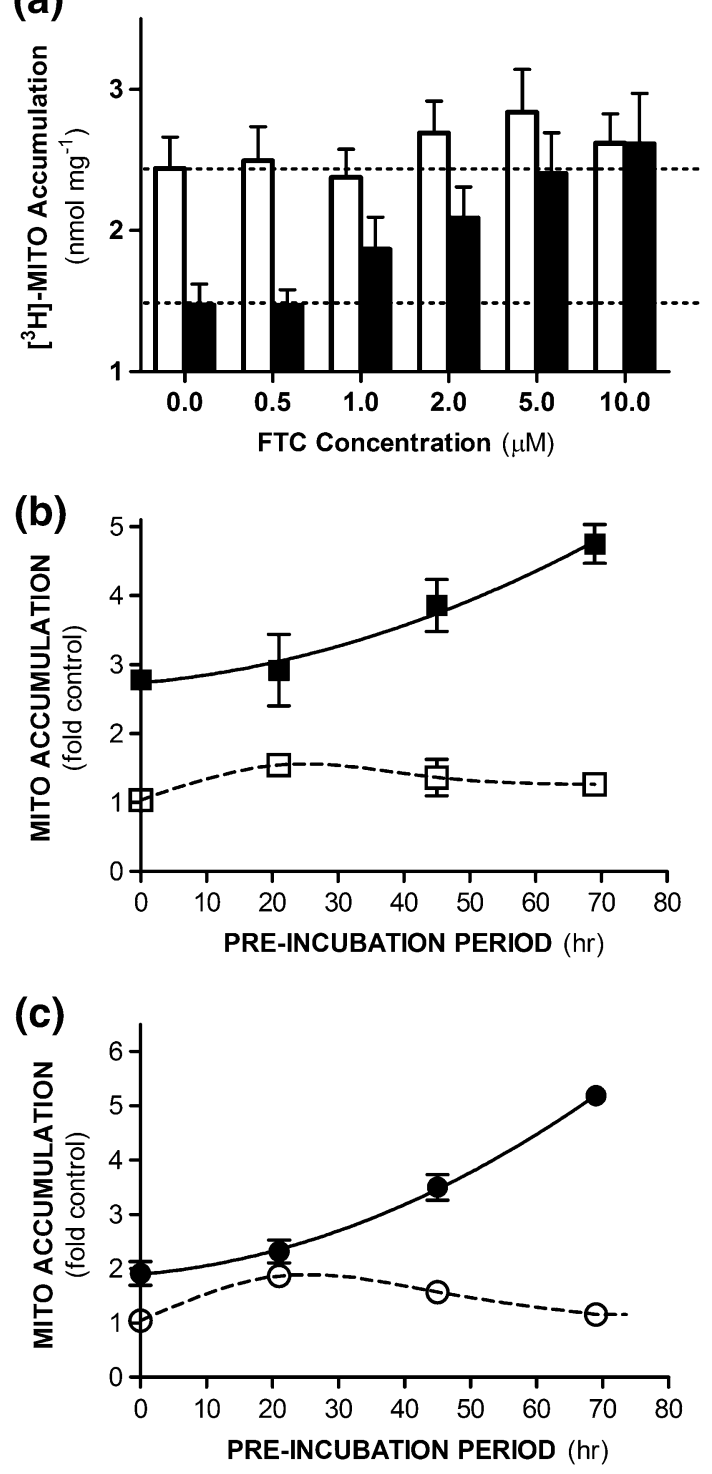

Fig. $4\left[{ }^{3} \mathrm{H}\right]$-mitoxantrone accumulation in breast cancer cell lines. a MCF7 (open bars) and MCF7 FLV1000 (filled bars) grown in 6-well plates were incubated with $\left[{ }^{3} \mathrm{H}\right]$-mitoxantrone for $3 \mathrm{~h}$. Cells were also grown in the presence of varying concentrations $(0.5-10 \mu \mathrm{M})$ of the ABCG2 inhibitor FTC. Following incubation, the cells were washed and lysed and the amount of $\left[{ }^{3} \mathrm{H}\right]$-mitoxantrone determined by scintillation counting. MCF7 (open symbols, dashed lines) and MCF$7^{\mathrm{FLV} 1000}$ (filled symbols, solid lines) grown in 6-well plates were incubated with $\left[{ }^{3} \mathrm{H}\right]$-mitoxantrone in the presence or absence of $4 \mu \mathrm{M}$, b K00135 or c K00486. Cells were pre-incubated with Pim kinase inhibitors for periods shown in the graphs prior to addition of $\left[{ }^{3} \mathrm{H}\right]$ mitoxantrone. Following incubation with radiolabel, the cells were washed and lysed and the amount of $\left[{ }^{3} \mathrm{H}\right]$-mitoxantrone determined by liquid scintillation counting. Accumulation of $\left[{ }^{3} \mathrm{H}\right]$-mitoxantrone was expressed as a fraction of that obtained in the absence of Pim kinase inhibitor in each cell lines. The data shown represent the mean $\pm \mathrm{SD}$ of three independent experiments only during the transport incubation (acute treatment), or when the cells had been pre-incubated with the Pim1 inhibitor (for 21, 45 and $69 \mathrm{~h}$; chronic treatment) (Fig. 4b, c). The data were normalised to the level of $\left[{ }^{3} \mathrm{H}\right]$-mitoxantrone accumulation observed in the absence of Pim1 inhibitor, which was set to a value of 1.0. The increased exposure to Pim inhibitors reveals any long-term cellular effects on the activity or expression of Pim kinase.

Figure 4b demonstrates that the addition of K00135 did not result in any alteration of $\left[{ }^{3} \mathrm{H}\right]$-mitoxantrone accumulation in the MCF7 cell line, regardless of the incubation time. In contrast, the acute addition of K00135 $(2 \mu \mathrm{M})$ produced a 2.6-fold increase in the steady-state accumulation of $\left[{ }^{3} \mathrm{H}\right]$ mitoxantrone in $\mathrm{MCF}^{\mathrm{FLV} 1000}$ cells (comparable to the twofold change in accumulation effected by FTC treatment; Fig. 4a). This result in $\mathrm{MCF}^{\mathrm{FLV} 1000}$ cells suggests a direct effect on the activity of ABCG2. Additionally, we observed that extended pre-incubation of these cells with K00135 produced a significant, and time-dependent, increase in the accumulation of $\left[{ }^{3} \mathrm{H}\right]$-mitoxantrone. These data suggest that the compound also produces a chronic effect on ABCG2 activity resulting from inhibition of Pim1 kinase.

Similarly, Fig. $4 c$ shows the effects of K00486 $(2 \mu \mathrm{M})$ on $\left[{ }^{3} \mathrm{H}\right]$-mitoxantrone accumulation in the two cell lines. Similarly, the Pim1 inhibitor did not generate any significant alterations in radiolabel accumulation in the drugsensitive MCF7 cells. However, there were time-dependent alterations of $\left[{ }^{3} \mathrm{H}\right]$-mitoxantrone in the drug-resistant MCF$7^{\mathrm{FLV} 1000}$ cells. The accumulation was increased 1.9-fold where there was no pre-incubation with K00486, and following a 69-h pre-incubation, the level had been increased over fivefold. $\left[{ }^{3} \mathrm{H}\right]-$ Mitoxantrone accumulation was also increased using a higher concentration of Pim1 inhibitors (i.e. $4 \mu \mathrm{M}$ ); however, this did not differ markedly from the observations reported for the lower concentration. In addition, the prolonged exposure of $\mathrm{MCF}^{\mathrm{FLV} 1000}$ cells to the direct-acting ABCG2 inhibitor FTC $(5 \mu \mathrm{M})$ did not result in a similar time-dependent modification of mitoxantrone accumulation (data not shown).

In summary, the Pim1 inhibitors appear to display both short- and long-term effects on the accumulation of the ABCG2 substrate $\left[{ }^{3} \mathrm{H}\right]$-mitoxantrone in the $\mathrm{MCF} 7^{\mathrm{FLV} 1000}$ cell line. There were no effects in the drug-sensitive MCF7 cells, suggesting that this effect was specifically related to ABCG2. Short-term effects are likely to involve direct inhibition of the protein although the 3-h duration of this assay does not entirely rule out post-translational effects. The long-term effects are likely to involve altered expression and/or post-translational modification of ABCG2. 
(a)
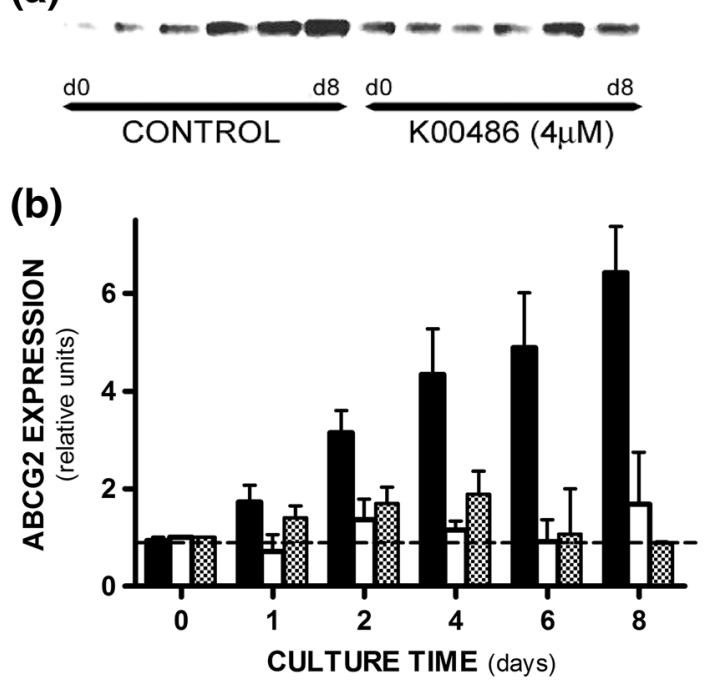

Fig. 5 Effects of Pim1 kinase inhibitors on the expression of ABCG2 in cancer cells. MCF7 ${ }^{\mathrm{FLV} 1000}$ cells were grown in the absence or presence of Pim kinase inhibitors for up to 8 days. a Cell lysates were prepared from the drug-resistant $\mathrm{MCF}^{\mathrm{FLV} 1000}$ cell line in $1 \%$ SDS and total protein determined colorimetrically. SDS-PAGE (10\% gels) and western blot analysis was performed on lysate samples containing $4 \mu \mathrm{g}$ protein. ABCG2 was detected using the BXP-21 antibody. The upper panel shows ABCG2 expression in the absence of inhibitor and the lower panel in the presence of $4 \mu \mathrm{M}$ K00486. The panels represent data from a representative experiment. b Relative ABCG2 expression was quantified using densitometry and plotted as a function of time in culture. The MCF $7^{\mathrm{FLV} 1000}$ cells were grown in the presence of DMSO control (black bars), $4 \mu \mathrm{M}$ K00135 (white bars) or $4 \mu \mathrm{M}$ K004865 (hashed bars). The data represent mean $\pm \mathrm{SEM}$ from four independent experiments

\section{The effects of Pim1 inhibitors on total expression of $\mathrm{ABCG} 2$ in $\mathrm{MCF} 7^{\mathrm{FLV1000}}$ cells}

The ability of the Pim1 inhibitors to alter the expression of ABCG2 was investigated by western blot analysis on MCF$7^{\text {FLV1000 }}$ cells following incubation with the compounds for 8 days. Data on the expression levels of ABCG2 are shown in Fig. 5.

Figure 5a demonstrates a representative western immuno-blot of $\mathrm{ABCG} 2$ expression for $\mathrm{MCF} 7^{\mathrm{FLV} 1000}$ cells in the absence or presence of $4 \mu \mathrm{M}$ K00486 over an 8-day period. The intensity of ABCG2 bands was quantified using densitometry and the results from four preparations expressed as a function of culture time (Fig. 5b). The initial time point was obtained $24 \mathrm{~h}$ following cell seeding and displayed low-level ABCG2 expression. During the 8-day culture period, the expression of ABCG2 increased fivefold to sixfold in the MCF7 ${ }^{\mathrm{FLV} 1000}$ cells. In contrast, in the presence of Pim1 inhibitors, the expression of ABCG2 did not alter significantly during this period and remained similar at day 8 compared to day 0 .
The expression data reveal a considerable reduction in the levels of ABCG2 in MCF7 ${ }^{\mathrm{FLV} 1000}$ cells following the addition of Pim inhibitors. Thus, the ability of these compounds to overcome drug resistance is also related to the progressive diminution of ABCG2 expression. This effect is in addition to the ability to interact directly with ABCG2 and thereby impair cytotoxic drug efflux.

\section{Discussion}

The investigation has revealed that multidrug resistance conferred by ABCG2 was overcome by two imidazo-pyridazine derivatives, which had previously been developed as specific inhibitors of the serine/threonine kinase Pim1. Earlier studies have demonstrated that co-expression of Pim1 and ABCG2 produces increased resistance and that the proteins share a physical interaction [13]. In this study, we have shown that both inhibitors overcame ABCG2-mediated resistance by directly modulating transport of the substrate mitoxantrone. Further investigation on the transport process additionally revealed a longer-term effect that was associated with reduced expression of ABCG2 in the cancer cell lines. This two-pronged approach provides a novel alternative to the classical approach of exclusively targeting the transporter. Potent and selective modulation of regulatory kinase proteins may alleviate the problems with developing specific inhibitors of polyspecific drug transporters such as ABCG2, as we provided evidence that K00135 and K00486 are themselves not transport substrates of ABCG2.

Amongst the earliest reports on the function of Pim kinase were the observations that the protein weakly transformed mesenchymal cells to generate lymphoma and leukaemia [30, 31]. Furthermore, elevated expression of Pim kinase was observed in human myeloid leukaemia and lymphoma [32, 33]. As the biology of the kinase became more widely investigated, a role in solid tumours became apparent, with expression demonstrated in prostate, gastric, hepatic, bladder and colorectal tumours [16, 23, 34, 35]. The tumour growth stimulating properties of Pim kinase [36, 37] render the protein a target for therapeutic intervention in cancer. The present investigation demonstrated growth inhibition of a panel of cancer cell lines derived from haematological malignancies and solid tumours by two potent imidazo-pyridazine-based inhibitors of Pim kinase. This efficacy further supports an inherent role for Pim kinases in tumour biology. The potency of the Pim inhibitors to produce growth inhibition was in the low micromolar range, which was similar to cisplatin, but lower than most cytotoxic chemotherapy drugs.

In the last decade, medicinal chemistry efforts have generated several classes of Pim kinase inhibitors [38, 39]. The "boom" in production of inhibitor compounds has benefited 
from the availability of high-resolution structural data for Pim kinases [24]. For example, the K00135 inhibitor used in the present study co-crystallises with Pim1, and numerous derivatives have been developed from knowledge of the molecular interactions underpinning binding [24].

The ABCG2-expressing cells displayed considerable differences in the level of resistance to a range of anti-cancer drugs and other compounds, as shown in Table 1 and in the review by Nakanishi et al. [40]. The range of resistance (and the relative order) to anti-cancer drugs in the current investigation is in broad agreement with previous work using the MCF7 ${ }^{\mathrm{FLV} 1000}$ cell line [2]. The mycotoxin FTC was one of the first inhibitors of ABCG2 to be identified by virtue of its ability to restore sensitivity of drug-resistant cell lines to topotecan, mitoxantrone and doxorubicin [41]. The potency of FTC to overcome ABCG2-mediated resistance was in the range $0.1-5 \mu \mathrm{M}$. In the present investigation, a fixed concentration of FTC $(0.3 \mu \mathrm{M})$ produced a reduction in the extent of resistance by a factor of up to tenfold and thereby restored sensitivity to anti-cancer drugs to levels similar to the MCF7 cell line.

The potencies of K00135 and K00486 to inhibit Pim1 kinase have been demonstrated as 0.12 and $0.04 \mu \mathrm{M}$, respectively, whereas the potency to inhibit Pim2 kinase was reduced by up to 50-fold [24]. Both Pim1 kinase inhibitors, at concentrations of $0.1-1 \mu \mathrm{M}$, were able to reduce the extent of resistance to anti-cancer drugs in the MCF$7^{\mathrm{FLV} 1000}$ cell line. Furthermore, the potencies and efficacies were similar to that of FTC. In addition, the potencies to overcome the resistant phenotype in ABCG2-expressing cells were similar to another imidazo-pyridazine compound SGI-1776, which reached late-stage clinical trials [42]. In contrast to the inhibitor SGI-1776, which was able to inhibit and overcome the actions of ABCB1 in cancer cell lines [42], K00135 and K00486 were selective for ABCB1. However, SGI-1776 differs markedly in chemical structure from K00135/K00486, despite the common imidazo-pyridazine moiety. It is therefore likely that the different substituents in SGI-1776 enhance its ability to interact directly with ABCB1.

These data clearly indicate that inhibition of Pim kinase can overcome the resistant phenotype produced by expression of ABCG2 and the subsequent focus was to ascertain the underlying mechanism. It has been widely demonstrated that $\mathrm{ABCG} 2$ confers resistance in the $\mathrm{MCF} 7^{\mathrm{FLV} 1000}$ cell line by preventing accumulation of drugs such as mitoxantrone $[2,41]$. The assay required a long incubation period (i.e. $3 \mathrm{~h}$ ) in order that the accumulation of $\left[{ }^{3} \mathrm{H}\right]$-mitoxantrone reached a steady state, which is in agreement with previous studies [2, 41]. The addition of both Pim kinase inhibitors increased the extent of mitoxantrone accumulation, which suggests a direct interaction between the Pim inhibitors and ABCG2. SGI-1776 was shown to produce similar effects on mitoxantrone accumulation in ABCG2-expressing cells [42]. Classically, inhibitors of multidrug efflux pumps from the $\mathrm{ABC}$ family have been generated to interact with the drug-binding site and thereby reduce the rate of substrate translocation. However, the Pim inhibitors used in this study were designed to bind at the catalytic domain of the kinase. The Pim1 protein has an ATP-binding domain that is distinct from most kinases [24, 38]. Structural data demonstrated that K00135 and K00486 do not bind to the "kinase hinge region" as predicted, but to the novel N-terminal helix within the catalytic region. Therefore, although they interact at the ATP-binding domain, they are not considered ATP mimetics. Consequently, this provides a high selectivity for the catalytic domain of Pim proteins and only interacted with one other protein from a panel of over fifty Ser/Thr kinases [24]. Therefore, it is highly unlikely that K00135 and K00486 interact with the ATP-binding domain of $\mathrm{ABC}$ transporters such as ABCG2.

Thus, the short-term effects of the Pim1-kinase inhibitors are likely to be mediated either through direct effects on ABCG2 activity per se, or via indirect effects on ABCG2 phosphorylation by Pim1. An investigation by Xie et al. [13] provides considerable evidence for the latter. For example, the two proteins are co-expressed in several drugresistant cell lines and co-localise at the plasma membrane. The investigation also suggested that threonine-362 in ABCG2 was phosphorylated by Pim1. Knocking down the expression of Pim1 reduced the oligomerisation of ABCG2, which rendered the cells sensitive to mitoxantrone and doxorubicin. This suggests that Pim1 is an important factor in the multidrug-resistant phenotype conferred by ABCG2. This confirms our observation that pharmacological inhibition of Pim1 kinase is able to overcome ABCG2-mediated resistance. Moreover, it supports the proposal that Pim1 kinase inhibitor-mediated disruption of $\left[{ }^{3} \mathrm{H}\right]$-mitoxantrone accumulation may be due to disruption of the stability of ABCG2 oligomers at the plasma membrane.

In parallel with post-translational effects on $\mathrm{ABCG} 2$ activity, we also have provided evidence for a chronic effect on ABCG2 expression level. Culture of $\mathrm{MCF}^{\mathrm{FLV} 1000}$ cells revealed a hyperbolic increase in $\mathrm{ABCG} 2$ expression, which was severely reduced in the presence of both Pim1 kinase inhibitors. A precedent for this has already been observed; surface expression of ABCG2 was reduced in cells treated with another Pim kinase inhibitor, SGI-1776 [42]. Control of ABCG2 expression is complex, involves numerous overlapping pathways and is frequently cell, or tissue, specific $[40,43]$. Two of the most frequently observed control factors for ABCG2 expression are Pim kinase and the PI3K/ AKT signalling pathway [13, 14, 27]. For example, inhibition of BCR-ABL by imatinib in resistant K562 leukaemic cells was associated with post-transcriptional regulation of ABCG2 expression via PI3K/AKT [44]. It is tempting to 
speculate that the K00135/K00486-mediated reduction in ABCG2 expression involves the coordinated effects of Pim kinase and the PI3K/AKT pathway at a transcriptional or post-transcriptional level. The pathway or mechanism of interaction and synergy between these two factors remains to be established to date.

The data indicate that Pim kinase inhibition by the two imidazo-pyridazine compounds is able to circumvent ABCG2-mediated multidrug resistance. The mechanism underlying this effect is by reducing the expression level of ABCG2 in the cells. Based on previous findings that Pim kinase and ABCG2 share a physical interaction [13], it is tempting to speculate that phosphorylation of ABCG2 is important in the stability of the protein at the plasma membrane. Moreover, it provides further proof that the drugresistant phenotype may be circumvented or overcome via modulation of regulatory protein activity and in the case of ABCG2, Pim kinase is a key target.

Acknowledgments This investigation was funded by a project Grant (090072/Z/09/Z) from the Wellcome Trust awarded to Richard Callaghan and Stefan Knapp. SK is grateful for support by the SGC, a registered charity (number 1097737) that receives funds from AbbVie, Bayer, Boehringer Ingelheim, the Canada Foundation for Innovation, the Canadian Institutes for Health Research, Genome Canada, GlaxoSmithKline, Janssen, Lilly Canada, the Novartis Research Foundation, the Ontario Ministry of Economic Development and Innovation, Pfizer, Takeda, and the Wellcome Trust (092809/Z/10/Z).

\section{References}

1. Doyle LA, Yang WD, Abruzzo LV, Krogmann T, Gao YM, Rishi AK, Ross DD (1998) A multidrug resistance transporter from human MCF-7 breast cancer cells. Proc Natl Acad Sci USA 95(26):15665-15670

2. Robey RW, Medina-Perez WY, Nishiyama K, Lahusen T, Miyake K, Litman T, Senderowicz AM, Ross DD, Bates SE (2001) Overexpression of the ATP-binding cassette half-transporter, ABCG2 (MXR/BCRP/ABCP1), in flavopiridol-resistant human breast cancer cells. Clin Cancer Res 7(1):145-152

3. Fellner S, Bauer B, Miller DS, Schaffrik M, Fankhanel M, Spruss T, Bernhardt G, Graeff C, Farber L, Gschaidmeier H, Buschauer A, Fricker G (2002) Transport of paclitaxel (Taxol) across the blood-brain barrier in vitro and in vivo. J Clin Investig 110(9):1309-1318

4. Robey RW, Polgar O, Deeken J, To KW, Bates SE (2007) ABCG2: determining its relevance in clinical drug resistance. Cancer Metastasis Rev 26(1):39-57. doi:10.1007/ s10555-007-9042-6

5. Ross DD, Wooten PJ, Tong Y, Cornblatt B, Levy C, Sridhara R, Lee EJ, Schiffer CA (1994) Synergistic reversal of multidrugresistance phenotype in acute myeloid-leukemia cells by cyclosporine-A and cremophor EL. Blood 83(5):1337-1347

6. Scheffer GL, Maliepaard M, Pijnenborg ACLM, van Gastelen MA, de Jong MC, Schroeijers AB, van der Kolk DM, Allen JD, Ross DD, van der Valk P, Dalton WS, Schellens JHM, Scheper RJ (2000) Breast cancer resistance protein is localized at the plasma membrane in mitoxantrone- and topotecan-resistant cell lines. Cancer Res 60(10):2589-2593
7. Ozvegy C, Litman T, Szakacs G, Nagy Z, Bates S, Varadi A, Sarkadi B (2001) Functional characterization of the human multidrug transporter, ABCG2, expressed in insect cells. Biochem Biophys Res Commun 285(1):111-117. doi:10.1006/ bbrc. 2001.5130

8. McDevitt CA, Collins RF, Conway M, Modok S, Storm J, Kerr ID, Ford RC, Callaghan R (2006) Purification and 3D structural analysis of oligomeric human multidrug transporter ABCG2. Structure 14(11):1623-1632. doi:10.1016/j.str.2006.08.014

9. Diop NK, Hrycyna CA (2005) N-linked glycosylation of the human ABC transporter ABCG2 on asparagine 596 is not essential for expression, transport activity, or trafficking to the plasma membrane. Biochemistry 44(14):5420-5429. doi:10.1021/ Bi0479858

10. Henriksen U, Fog JU, Litman T, Gether U (2005) Identification of intra- and intermolecular disulfide bridges in the multidrug resistance transporter ABCG2. J Biol Chem 280(44):3692636934. doi:10.1074/jbc.M502937200

11. Polgar O, Robey RW, Morisaki K, Dean M, Michejda C, Sauna ZE, Ambudkar SV, Tarasova N, Bates SE (2004) Mutational analysis of ABCG2: role of the GXXXG motif. Biochemistry 43(29):9448-9456. doi:10.1021/Bi0497953

12. Takada T, Suzuki H, Gotoh Y, Sugiyama Y (2005) Regulation of the cell surface expression of human BCRP/ABCG2 by the phosphorylation state of Akt in polarized cells. Drug Metab Dispos 33(7):905-909. doi:10.1124/dmd.104.003228

13. Xie Y, Xu K, Linn DE, Yang X, Guo Z, Shimelis H, Nakanishi T, Ross DD, Chen H, Fazli L, Gleave ME, Qiu Y (2008) The 44-kDa Pim-1 kinase phosphorylates BCRP/ABCG2 and thereby promotes its multimerization and drug-resistant activity in human prostate cancer cells. J Biol Chem 283(6):3349-3356. doi:10.1074/jbc.M707773200

14. Mogi M, Yang J, Lambert JF, Colvin GA, Shiojima I, Skurk C, Summer R, Fine A, Quesenberry PJ, Walsh K (2003) Akt signaling regulates side population cell phenotype via Bcrp1 translocation. J Biol Chem 278(40):39068-39075. doi:10.1074/jbc. M306362200

15. Krishnan N, Pan HQ, Buckley DJ, Buckley AR (2003) Prolactin-regulated Pim-1 transcription. Endocrine 20(1-2):123-129. doi:10.1385/Endo:20:1-2:123

16. Shah N, Pang B, Yeoh KG, Thorn S, Chen CS, Lilly MB, SaltoTellez M (2008) Potential roles for the PIM1 kinase in human cancer-a molecular and therapeutic appraisal. Eur J Cancer 44(15):2144-2151. doi:10.1016/j.ejca.2008.06.044

17. Saris CJM, Domen J, Berns A (1991) The Pim-1 oncogene encodes 2 related protein-serine threonine kinases by alternative initiation at AUG and CUG. EMBO J 10(3):655-664

18. Leverson JD, Koskinen PJ, Orrico FC, Rainio EM, Jalkanen KJ, Dash AB, Eisenman RN, Ness SA (1998) Pim-1 kinase and p100 cooperate to enhance c-Myb activity. Mol Cell 2(4):417-425. doi:10.1016/S1097-2765(00)80141-0

19. Mochizuki T, Kitanaka C, Noguchi K, Muramatsu T, Asai A, Kuchino Y (1999) Physical and functional interactions between Pim-1 kinase and Cdc25A phosphatase-implications for the Pim-1-mediated activation of the c-Myc signaling pathway. J Biol Chem 274(26):18659-18666. doi:10.1074/ jbc.274.26.18659

20. Koike N, Maita H, Taira T, Ariga H, Iguchi-Ariga SMM (2000) Identification of heterochromatin protein 1 (HP1) as a phosphorylation target by Pim-1 kinase and the effect of phosphorylation on the transcriptional repression function of HP1. FEBS Lett 467(1):17-21. doi:10.1016/S0014-5793(00)01105-4

21. Xie XM, Zhao XQ, Liu YF, Zhang JF, Matusik RJ, Slawin KM, Spencer DM (2001) Adenovirus-mediated tissue-targeted expression of a caspase-9-based artificial death switch for the treatment of prostate cancer. Cancer Res 61(18):6795-6804 
22. Palaty CK, ClarkLewis I, Leung D, Pelech SL (1997) Phosphorylation site substrate specificity determinants for the Pim-1 protooncogene-encoded protein kinase. Biochem Cell BiolBiochimie Et Biologie Cellulaire 75(2):153-162. doi:10.1139/ Bcb-75-2-153

23. Mumenthaler SM, Ng PYB, Hodge A, Bearss D, Berk G, Kanekal S, Redkar S, Taverna P, Agus DB, Jain A (2009) Pharmacologic inhibition of Pim kinases alters prostate cancer cell growth and resensitizes chemoresistant cells to taxanes. Mol Cancer Ther 8(10):2882-2893. doi:10.1158/1535-7163. Mct-09-0293

24. Pogacic V, Bullock AN, Fedorov O, Filippakopoulos P, Gasser C, Biondi A, Meyer-Monard S, Knapp S, Schwaller J (2007) Structural analysis identifies imidazo[1,2-b]pyridazines as PIM kinase inhibitors with In vitro antileukemic activity. Cancer Res 67(14):6916-6924. doi:10.1158/0008-5472.Can-07-0320

25. Bullock AN, Debreczeni J, Amos AL, Knapp S, Turk BE (2005) Structure and substrate specificity of the Pim-1 kinase. J Biol Chem 280(50):41675-41682. doi:10.1074/jbc.M510711200

26. Bullock AN, Debreczeni JE, Fedorov OY, Nelson A, Marsden BD, Knapp S (2005) Structural basis of inhibitor specificity of the human protooncogene proviral insertion site in moloney murine leukemia virus (PIM-1) kinase. J Med Chem 48(24):7604-7614. doi:10.1021/jm0504858

27. Isaac M, Siu A, Jongstra J (2011) The oncogenic PIM kinase family regulates drug resistance through multiple mechanisms. Drug Resist Updates 14(4-5):203-211. doi:10.1016/j. drup.2011.04.002

28. Scudiero DA, Monks A, Sausville EA (1998) Cell line designation change: multidrug-resistant cell line in the NCI anticancer screen. J Natl Cancer Inst 90(11):862

29. Rivers F, O'Brien TJ, Callaghan R (2008) Exploring the possible interaction between anti-epilepsy drugs and multidrug efflux pumps; in vitro observations. Eur J Pharmacol 598(1-3):1-8. doi:10.1016/j.ejphar.2008.09.014

30. Moroy T, Grzeschiczek A, Petzold S, Hartmann KU (1993) Expression of a Pim-1 transgene accelerates lymphoproliferation and inhibits apoptosis in lpr/lpr mice. Proc Natl Acad Sci USA 90(22): 10734-10738

31. Moroy T, Verbeek S, Ma A, Achacoso P, Berns A, Alt F (1991) E mu N- and E mu L-myc cooperate with E mu Pim-1 to generate lymphoid tumors at high frequency in double-transgenic mice. Oncogene 6(11):1941-1948

32. Nieborowska-Skorska M, Hoser G, Kossev P, Wasik MA, Skorski T (2002) Complementary functions of the antiapoptotic protein $\mathrm{A} 1$ and serine/threonine kinase Pim-1 in the BCR/ABLmediated leukemogenesis. Blood 99(12):4531-4539
33. Selten G, Cuypers HT, Berns A (1985) Proviral activation of the putative oncogene Pim-1 in MuLV induced T-cell lymphomas. EMBO J 4(7):1793-1798

34. Bachmann M, Moroy $\mathrm{T}$ (2005) The serine/threonine kinase Pim-1. Int J Biochem Cell Biol 37(4):726-730. doi:10.1016/j. biocel.2004.11.005

35. Guo S, Mao X, Chen J, Huang B, Jin C, Xu Z, Qiu S (2010) Overexpression of Pim-1 in bladder cancer. J Exp Clin Cancer Res 29:161. doi:10.1186/1756-9966-29-161

36. Wang Z, Bhattacharya N, Weaver M, Petersen K, Meyer M, Gapter L, Magnuson NS (2001) Pim-1: a serine/threonine kinase with a role in cell survival, proliferation, differentiation and tumorigenesis. J Vet Sci 2(3):167-179

37. White E (2003) The pims and outs of survival signalling: role for the Pim-2 protein kinase in the suppression of apoptosis by cytokines. Genes Dev 17(15):1813-1816. doi:10.1101/ gad. 1123103

38. Qian KC, Wang L, Hickey ER, Studts J, Barringer K, Peng C, Kronkaitis A, Li J, White A, Mische S, Farmer B (2005) Structural basis of constitutive activity and a unique nucleotide binding mode of human Pim-1 kinase. J Biol Chem 280(7):6130 6137. doi:10.1074/jbc.M409123200

39. Swords R, Kelly K, Carew J, Nawrocki S, Mahalingam D, Sarantopoulos J, Bearss D, Giles F (2011) The Pim kinases: new targets for drug development. Curr Drug Targets 12(14):2059-2066

40. Nakanishi T, Ross DD (2012) Breast cancer resistance protein (BCRP/ABCG2): its role in multidrug resistance and regulation of its gene expression. Chin J Cancer 31(2):73-99. doi:10.5732/ cjc. 011.10320

41. Rabindran SK, Ross DD, Doyle LA, Yang W, Greenberger LM (2000) Fumitremorgin C reverses multidrug resistance in cells transfected with the breast cancer resistance protein. Cancer Res 60(1):47-50

42. Natarajan K, Bhullar J, Shukla S, Burcu M, Chen ZS, Ambudkar SV, Baer MR (2013) The Pim kinase inhibitor SGI-1776 decreases cell surface expression of P-glycoprotein (ABCB1) and breast cancer resistance protein (ABCG2) and drug transport by Pim-1-dependent and -independent mechanisms. Biochem Pharmacol 85(4):514-524. doi:10.1016/j.bcp.2012.12.006

43. Callaghan R, Crowley E, Potter S, Kerr ID (2008) P-glycoprotein: so many ways to turn it on. J Clin Pharmacol 48(3):365-378

44. Nakanishi T, Shiozawa K, Hassel BA, Ross DD (2006) Complex interaction of BCRP/ABCG2 and imatinib in BCR-ABLexpressing cells: BCRP-mediated resistance to imatinib is attenuated by imatinib-induced reduction of BCRP expression. Blood 108(2):678-684. doi:10.1182/blood-2005-10-4020 